REGARDS

SUR LEECONOMIE ALLEMANDE

BULLETIN ECONOMIQUE DU CRAC

\section{Regards sur l'économie allemande}

Bulletin économique du CIRAC

$86 \mid 2008$

Varia

\title{
Marché du travail
}

OHR Renate (ed), Arbeitsmarkt und Beschäftigung

\section{(2) OpenEdition}

\section{Journals}

Édition électronique

URL : http://journals.openedition.org/rea/763

DOI : $10.4000 /$ rea.763

ISBN : 978-2-8218-0868-3

ISSN : 1965-0787

\section{Éditeur}

CIRAC

\section{Édition imprimée}

Date de publication : 1 mai 2008

ISSN : 1156-8992

\section{Référence électronique}

"Marché du travail », Regards sur l'économie allemande [En ligne], 86 | mai 2008, document 5, mis en ligne le 14 mai 2008, consulté le 22 septembre 2020. URL : http://journals.openedition.org/rea/763 ; DOI : https://doi.org/10.4000/rea.763

Ce document a été généré automatiquement le 22 septembre 2020

(c) CIRAC 


\title{
Marché du travail
}

\author{
OHR Renate (ed), Arbeitsmarkt und Beschäftigung
}

\section{RÉFÉRENCE}

OHR Renate (ed), Arbeitsmarkt und Beschäftigung, Schriften des Vereins für Socialpolitik, vol. 318, Duncker\&Humblot, Berlin, 2007, 228 p.

1 Ces actes d'un colloque sur "Le marché du travail et l'emploi » organisé à Francfort voici un an par le Verein für Socialpolitik passent au crible les mutations lourdes et les grands enjeux sous-tendant l'évolution des approches politiques en Allemagne, mais aussi aux Pays-Bas. L'une des contributions, co-signée par l'un des membres de la Commission des monopoles, sorte de conseil d'analyse scientifique de l'office fédéral des Cartels (Haucap et al.) apporte un éclairage nouveau sur l'ampleur des bouleversements que connaît le partenariat social allemand. Et, du fait de la concurrence intersyndicale croissante, elle préconise de considérer dorénavant ce dernier aussi à la lumière du droit des cartels. (ib) 